\title{
The Impact of an Online Orientation Program on Student Success at a Community College
}

\author{
Rachel B. Lerner Colucci, B.A., Ed.M., Ed.D., Maryville University of
} St. Louis

Robin E. Grebing, B.S.Ed., M.B.A., Ed.D., Maryville University of St. Louis

This study examined the effectiveness of an online orientation program on participation and student success for a defined cohort of students at a mid-size community college in the mid-Atlantic region. Specifically, a quantitative analysis focused on differences in grade point average (GPA) and retention as success factors among students who completed the online orientation versus students who only started but did not finish and students who did not attempt the program. The findings indicate a statistically significant difference in fall-to-spring retention and first semester GPA for students who completed the online orientation module compared to students who accessed but did not complete and students who did not access the program. This study contributes to the research and literature on online orientation programs, specifically in the community college setting, and the researchers offer a discussion of results and recommendations for policy, practice, and future research.

\section{Introduction}

Since their inception, community colleges have focused on access as a critical role in their mission (21st Century Commission on the Future of Community Colleges, 2012; Bailey, Jaggars, \& Jenkins, 2015; Cooper, n.d.; Karp, Hughes, \& O'Gara, 2008; Troyer, 2015). By providing access geographically close to home and at a low cost, community colleges offer a path for students who are underprepared academically or financially 
or may be otherwise unable to attend a traditional 4-year college or university due to family, work, or personal obligations (Cooper, n.d.; Fike \& Fike, 2008; Karp et al., 2008; Schneider \& Yin, 2012).

Researchers and practitioners have comprehensively studied the significance and impact of student success programs, including new student orientation programs (Nguyen, Hays, \& Weinstein, 2010; Robichaud, 2016b). Characteristics of the student population and enrollment timeline of community colleges pose challenges in providing comprehensive and effective orientation programs for new students. Students are often applying and registering for courses only weeks, days, or even hours before the start of an academic semester. Many community college students also have competing priorities, including work and family obligations, which reduce their ability to spend time on campus. These factors make it difficult for students to attend a traditional, on-campus, new student orientation session, yet provide all the more reason they need this critical information (Boyd, Largent, \& Rondeau., 2008; Fike \& Fike, 2008; Karp et al., 2008).

While not all students who choose to attend community college are at-risk, a significant percentage fall into that category. According to the Community College Research Center at Columbia University (n.d.), community colleges and other two-year public and private institutions enrolled nearly 6.3 million students in the fall of 2015. Of these students, approximately 2.3 million enrolled as full-time students, and another 4 million took classes on a part-time basis. Many students who enroll at community colleges are also more likely to be first-generation college students from low-income families, or come from historically underrepresented or minority racial backgrounds (Karp, 2011; Robichaud, 2016b).

Despite realizing the broad mission of access by enrolling large numbers of students and offering robust initiatives to support student success, retention and completion remain a challenge for community colleges across the nation (Cooper, n.d.; Dynarski, 2015; Juszkiewicz, 2017; Karp, 2011; Robichaud, 2016a). Fall-to-fall retention rates at community colleges hover around $62 \%$, which is alarming compared to the $81 \%$ retention rate at 4-year institutions (IPEDS, 2019). 
The graduation rate at public community colleges also lags behind that of the 4-year universities. The federal Integrated Postsecondary Education Data System, commonly referred to as IPEDS, reported a $31.5 \%$ graduation rate for students who enrolled at two-year postsecondary institutions in the Fall 2012 semester. In comparison, for students who began in 2012 at a 4-year degree-granting institution, the 6-year graduation rate is $58.6 \%$ (National Center for Education Statistics, n.d.).

To address the challenge of retaining students, community colleges offer a variety of interventions aimed at supporting student success, retention, and completion. These interventions include, but are not limited to, new student orientation programs, student success courses, tutoring and mentoring programs, academic advising and personal counseling, and even financial planning services (Center for Community College Student Engagement, 2018; Cooper, n.d.). Of these interventions, new student orientation has long been recognized as one of the most effective and meaningful programs to support success as students transition to the college environment (Ali \& Leeds, 2009; Tighe, 2008).

The literature is replete with studies on the impact of traditional, face-to-face, new student orientation programs (Harvey-Smith, n.d.; Robichaud, 2016b). Most of the research, however, focuses on traditionalage students at 4-year colleges and universities. As the demand for online courses has grown, online orientations have become increasingly prevalent at post-secondary institutions. There are, however, very limited studies which explore the role of an online orientation program or orientation programs at 2-year community colleges (Tighe, 2008).

Inspired by a true problem of practice, this action research study sought to understand how an online orientation program could be an effective strategy for community college students to improve retention, academic performance, and student success.

\section{Literatue Review}

In an era of increased accountability for student success paired with decreasing resources, community college leaders must develop new tools and strategies to support student retention and completion 
(Alijohani, 2016; Belfield, Jenkins, \& Fink, 2019; Schneider \& Yin, 2012; Wild \& Ebbers, 2002). Orientation programs have been identified as a best practice in supporting student success. Although there is a considerable amount of research on the topics of student success, retention, and new student orientation, the body of research and literature on both online orientation programs and community college orientations is more limited (Tighe, 2008; Wild \& Ebbers, 2002). This review of the literature discusses orientation programs, with a specific focus on community colleges and online orientation programs, to aid in understanding the research in this study and the recommendations for further study.

\section{Defining Student Success}

There are many ways to define student success. Common measures used to track student success include grade point average, persistence, retention, number of credits earned, and completion of a degree or certificate program (Belfield et al., 2019; Tighe, 2008). These measures, however, often pose challenges for community colleges. Due to the nature of the community college student population and learning environment, much of the research conducted on student retention in the university setting does not apply to the community college environment.

Most recently, Belfield, Jenkins, and Fink (2019) and Jenkins and Baily (2017) shared a set of Early Momentum Metrics, which may serve as indicators to predict longer-term success specifically for community college students. These metrics include persistence from the first to the second semester, first-year credit completion, and completion of collegelevel English and Math, or gateway courses.

Wild and Ebbers (2002) also present several ways various researchers and institutions have attempted to define retention for community colleges. These definitions include elements such as "maintenance of continued enrollment in classes throughout one semester" (p. 505), a calculation of courses completed compared to courses attempted in a given semester, achievement of one's personal academic goal, continued enrollment for two or more consecutive semesters, and/or completion of a degree or certificate program. 


\section{New Student Orientation}

New student orientation is an important, effective, and widely adopted part of the student onboarding experience (Chan, 2017; Garza Mitchell, 2014). NODA, the leading orientation, transition, and retention professional association, connects new student orientation to student success stating, "NODA believes that retention is one outcome/measure/ byproduct of successful student transition, which can be facilitated by effective orientation programs and other academic and social integration processes" (NODA, n.d., para. 3).

Orientation programs, designed as interventions to support student success, can take the form of a traditional face-to-face program on campus which is completed in a 1-2 day period on campus, welcome week programs, a semester-long orientation course, summer camp-style programs, and more recently as an online program students can take from anywhere (Garza Mitchell, 2014; NODA, n.d.; Robinson, Burns, \& Gaw, 1996; Scagnoli, 2001; Tighe, 2008). Barefoot (2005), as cited by Chan (2017), shares, "the findings of a national survey of first-year practices revealed that 96 percent of all U.S. secondary institutions offered some form of orientation program" (p. 14).

\section{Online Orientation Programs}

Adapting to pressures of time, decreasing resources, and increased technology, colleges and universities have begun to offer online orientation programs for targeted populations of students such as those in specific academic programs, students in online programs, or for international students (Jugdev \& Hutchinson, 2004; Koehnke, 2013; Taylor, Winn, \& Dunn, 2015; Valosik, 2014). Given the increased demand for online courses and online degree programs, colleges have developed online orientation programs to reach these students (Johnson, 2016; Robichaud, 2016a). The online format also enables colleges and universities with traditional academic programs to offer orientation in an easily accessible and flexible format (Hansen, Clark, McCleish, \& Hogan, 2009; Valosik, 2014).

Research shows more community colleges are offering online 
orientation programs to their student populations (Chan, 2017; Garza Mitchell, 2014; Gilroy, 2010; Jones, 2013; Robichaud, 2016a). The most recent NODA Databank survey, however, noted only 37\% of responding institutions offer some form of an online orientation, with most being offered as an alternative to an in-person orientation or targeted for special student populations (NODA: Association for Orientation, Transition, and Retention in Higher Education, 2017). Further, the 2018 Community College Survey of Student Engagement (CCSSE) reported only 14.5\% of community college students participated in an online orientation program (Center for Community College Student Engagement, 2018).

Chan (2017) analyzed a sample of online orientation programs, or e-orientations, to offer a comprehensive overview of such programs currently in existence at community colleges. Out of 891 community colleges, the study randomly selected 100 community colleges to conduct the study. Of these colleges, 20 institutions publicly indicated they offered an online orientation program.

\section{The Impact of Orientation Programs on Student Success}

Aligned with the call to action for improved completion rates, interventions to support student success are also becoming more prevalent in the community college setting. Programs such as developmental education, student success seminars, and orientation courses are designed to support community college students in achieving "academic and social engagement, and higher grades" (Hatch, MardockUman, Garcia, \& Johnson, 2018, p. 116). This section shares a brief overview of previous research seeking to understand the impact of orientation programs on student success.

Tighe (2008) found student participation in a college orientation course at Tidewater Community College significantly impacted student engagement, student satisfaction, academic achievement, and retention. In a sample of 1,316 students, those who participated in the orientation course demonstrated considerably higher levels of engagement, satisfaction, and retention than those who did not participate in the orientation course. 
Both Glass and Garrett (1995) and Nyugen, Hays, and Wetstein (2010) suggest participation in a semester-long orientation course has a positive effect on student success in the community college environment. Glass and Garrett (1995) conducted a study to determine if there was a relationship between completion of an orientation course and student success as measured by retention and GPA at community colleges in North Carolina. Of the 58 community colleges in North Carolina, 27 schools reported offering an orientation course. The courses varied in length from 10 to 44 hours, and some provided academic credit. Results of the study propose students who completed these courses completed significantly more credits and earned a higher GPA than those who did not complete an orientation course. While this study is somewhat dated, it establishes a clear foundation for studying the relationship between orientation and student retention for community college students (Glass \& Garrett, 1995).

In a study conducted at another community college in California, Nguyen et al. (2010) investigated the impact of an orientation course on student persistence as measured by fall-to-fall retention of a cohort of 5,427 new students. Approximately one-third of the sample cohort enrolled in the college's new student orientation course. The sample cohort included 32\% White students and 28\% Hispanic students with an average age of 20 years old and $31 \%$ of students having a low socioeconomic status. The results of the study indicated enrollment in the orientation course significantly increased the likelihood a student enrolling the following year. According to their findings, even after controlling for other variables, "students who enroll in the orientation course persist at a rate of $17.4 \%$ higher than students who do not enroll in the orientation course their first year" (Nguyen et al., 2010, p. 19).

Robichaud (2016a), Garza Mitchell (2014), and Jones (2013) agree that an online student orientation program for community college students in online courses supports increased retention outcomes. The programs generally include information on the college community, support resources and services, and, if specific to an online course, information on the online learning platform (Chan, 2017; Garza Mitchell, 2014; Gilroy, 2010; Jones, 2013; Robichaud 2016b). 
Robichaud (2016b) completed a qualitative case study to study the perceptions of six community college students enrolled in an online medical coding program. The researcher explored how an online orientation program impacted course completion and persistence in online courses. Personal themes including social interaction, time management, and commitment as well as technical themes such as the basics of an online classroom and consistency in course structure emerged as factors in student persistence and course completion. Participants in the study were generally positive about the online orientation program and data indicated the program should continue, although "social integration and interpersonal relationships, were areas where students perceived the need for improvement" (Robichaud, 2016b, p. 85-86).

Jones (2013) reported increased preparedness, confidence, and retention following the implementation of the mandatory online orientation program for first-time students enrolled in online and hybrid courses at Richland Community College. Richland Community College, a rural community college offering online courses, experienced an increase in retention rate for online courses from $71.8 \%$ to $79.5 \%$ with the required orientation program in place. Moreover, utilizing student and faculty feedback as well as retention and Help Desk data, the results indicated students were more prepared for the online courses, and $90 \%$ of students shared they felt more confident to succeed in their classes after completing the orientation (Jones, 2013).

Although the author does not offer details on the design and analysis of the assessment, this publication is significant because it addresses the relationship between an online orientation program and student success, and it identifies voluntary and in-person orientation programs were not effective at Richland Community College (Jones, 2013).

Garza Mitchell (2014) presents a case study analysis at Texas State Technical College Harlingen, a 2-year technical state college. After discovering their students in online courses were not as successful as their counterparts in traditional face-to-face courses, the college developed on online orientation program to address the concerns of online students. Similar to Jones (2013), the online program covered material 
related to using the learning management system, strategies for time management, and information on how to be successful in an online course environment. When the program was first implemented, the institution experienced a $94 \%$ completion rate by new online students; however, this later dropped to average a 74\% completion rate (Garza Mitchell, 2014).

This research by Garza Mitchell (2014) also suggests the program improves the completion rate of students in online courses. The withdrawal and failure rate of students in online courses dropped to 36$38 \%$ from $40-47 \%$ before the online orientation program was introduced. Additional discussion indicated faculty and staff supported this program beyond the online student population. Garza Mitchell states as a result of the successful launch of the online orientation for online students, the program was later added to the college's student success course for all Texas State Technical College Harlingen students.

\section{Summary}

In summary of the literature presented, there is significant evidence to support the impact of orientation programs on student academic achievement, student integration, and retention. Most studies also suggest an orientation program is essential to the academic and social integration to the college environment, whether at a traditional campus or in an online environment. Further, the literature demonstrates most orientation programs, regardless of delivery method, all include a similar selection of content. Yet, many of the publications only discuss the programs, processes, and experiences of implementing an online orientation program in the context of a specific campus or special population, or a snapshot of students' feedback on online orientation programs. There are few studies which discuss the results of the comprehensive effects of an online orientation program on a cohort of students. There is a gap in the research examining the effectiveness of online orientation programs for community college students. 


\section{Institutional Setting and Context}

\section{Setting}

The study was conducted at Bergen Community College in suburban Northern New Jersey. The college is an open-access, designated Hispanic Serving Institution (HSI), with a total enrollment of 14,062 students in the Fall 2017 semester. The college operates across three instructional sites; the main campus, and two smaller locations (Bergen Community College, 2018a). The institution offers over 100 academic programs, including degrees in Associate in Arts (AA), Associate in Science (AS), Associate in Applied Science (AAS), Associate in Fine Arts (AFA), and certificate courses of study. According to the institution's Fact Book (2018), the college awarded 2,315 degrees in 2017. The institution also services the community through a robust offering of non-credit and continuing education courses.

\section{Setting}

Despite numerous attempts to modify the traditional on-campus orientation program at Bergen Community College to increase participation, the number of students attending remained very low. According to archival data, 293 students attended an on-campus orientation program in 2013, 875 students in 2014, and 683 students in 2015 (H. Nkurunziza, personal communication, March 01, 2018). To add perspective, the college enrolled 15,883 students in 2013, 15,651 in 2014, and 14,585 in 2015 (Bergen, 2018a). Previous versions of the new student orientation program took many formats, including offering daytime and evening sessions, scheduling many small sessions throughout the summer, scheduling fewer larger sessions immediately before the new term, and presenting options on multiple days of the week at different times of the day.

The college launched an online orientation program as part of an effort to address student participation and improve retention rates by increasing opportunities to complete the orientation program. The 
program was developed in the Fall of 2015 and first made available to students in April 2016. Out of 4,426 students who enrolled for the first time at the college, 1,711 students accessed the online orientation program (Jacondin, 2018). Despite the increase in participation, not all new students were completing the program, and administrators at Bergen Community College questioned whether the program had an impact on student success and if the program should be mandatory.

\section{Research Questions}

This action research study focused on the impact of an online orientation program on two measures of student success: retention and grade point average. For the purposes of this study, retention is defined as fall-to-spring retention and grade point average (GPA) is the calculation of a student's earned grades based on the number of credits attempted. Success in relation to GPA is defined as being in good academic standing, which is measured as a GPA 2.0 or higher on a 4.0 scale. The research questions guiding this study are:

1. Is there a significant difference in the Fall 2018 cumulative GPA earned between students who complete the online orientation program at Bergen Community College and students who do not complete the program?

2. Is there a significant difference in Fall 2018 to Spring 2019 retention between students who complete the online orientation program at Bergen Community College and students who do not complete the program?

\section{Participants and Research Methods}

This action research study was designed to examine the participation, retention rates, and GPA for students who completed an online orientation program at a community college versus students who only accessed or did not complete the program. This section presents the methodology, research design, and participants in the study. 


\section{Methodology and Research Design}

Action Research. Huang (2010), defines action research as "an orientation to knowledge creation that arises in a context of practice and requires researchers to work with practitioners to effect desired changes along a path to generating knowledge and empowering stakeholders." Often used in educational settings, the authors selected a participatory action research approach to this project, which means the research focused on improving practice in the authors' own environment through focused effort and inquiry, and with the intent to utilize research to support organizational change (Edwards \& Willis, 2014; Stage \& Manning, 2016).

The online orientation program featured in this research at the time of the study was active in its third year at the institution where the study took place. Initial data indicating the number of students participating in the program seemed promising; however, there had been no organized or comprehensive attempt to collect, analyze, and systematically interpret the data to build effective programs and to inform policy and decision-making.

Research Design. To determine if participation in an online orientation program has an impact on student success, the researchers used institutional data from the college's student information system for students eligible to participate in the online orientation program for the Fall 2018 semester.

The institutional data is archival data of a quantitative nature. The data included student demographics, terms of enrollment, number of credits attempted, number of credits completed, GPA, and whether the student attempted or completed the online orientation program.

\section{Participants}

To assess student success indicators of GPA and retention, the sample included students who completed the online orientation program from April 1, 2018 to October 31, 2018 and registered as new full-time or part-time degree-seeking students at the college for the Fall 2018 semester. The sample excluded any high school dual-enrollment students, non-matriculated students, visiting students, international students, and 
students under 17 years old. These students are not part of the traditional degree-seeking student population this research is intended to study.

\section{Procedures}

All new students received initial notification of the online orientation program upon acceptance to the college in a Welcome Packet sent by the Admissions office. The students were prompted to log in to the online orientation program through the college web portal using their student ID issued by the college. In addition to the Welcome Packet from Admissions, all accepted students received a letter via email from the researcher, in the researcher's administrative role at the time of the study, inviting them to participate in the online orientation program. Because the college accepts students on a rolling basis, the letters were sent every two weeks to all newly accepted students prompting them to complete the online orientation program before the end of the first week of classes. Reminder emails were then sent to all students who accessed the online orientation program but did not complete it through the end of the second week of classes.

The researcher sent a notification using the college's email system to all students who (a) attempted and/or completed the online orientation program, (b) enrolled for the first time at the college for the Fall 2018 semester, (c) identified as degree- and/or certificate-seeking, and (d) were 18 or older. The notification explained that information collected from the online orientation program was to be used in a doctoral student research project and that they may request to view the results of the completed research. The notice explained all data would be analyzed in aggregate form, and no personally identifiable information would be shared to ensure student privacy is protected.

\section{Analysis of Data}

This section presents the results of the action research study to better understand the impact of participation in an online orientation program on student success. As an active program, the college's online orientation 
program software platform and student information system collected and generated a rich set of data on students who participated in the program. Data obtained from the institution's student information system examined the sample's enrollment and registration status from the Fall 2018 semester to the Spring 2019 semester to determine retention and cumulative GPA attained during the Fall 2018 semester.

Using a secondary-data analysis, the researcher conducted a set of statistical tests utilizing the Statistical Package for the Social Sciences (SPSS). Descriptive statistics, ANOVA, and Chi-Square tests were performed to determine if there were significant differences in the two measures of student success, fall-to-spring retention and first semester GPA, in the sample population ( $\mathrm{N}=3281$ ). For the purposes of this analysis, the sample was grouped into three categories: students who completed the online orientation $(1284,39.1 \%)$, students who attempted the online orientation $(790,24.1 \%)$, and students who made no attempt at the program $(1207,36.8 \%)$.

\section{Description of the sample}

The sample included 3,281 students ( $\mathrm{N}=3281)$, with a slightly higher number of males participating. More than three-quarters of the students (2490, 75.9\%) were in the 18-21 age range. Further, 272 (8.3\%) students were in the 22-24 age range, 323 (9.8\%) were 25-34, and 196 (6.0\%) were over 35 years old.

Of the sample population, the largest groups identified as Hispanic (1303, 39.7\%) followed closely by White students (1145, 34.9\%).

There were also 307 (9.4\%) Asian students and 249 (7.6\%) students identifying as Black/African American. Table 1 presents an overview of the demographics for the sample student population presented in this study. 


\section{Table 1}

Descriptive Statistics for the Sample of Eligible Sample Participants $(N=3281)$

\begin{tabular}{lll}
\hline Demographic item & Frequency & Percentage \\
\hline Race/Ethnicity & & \\
\hline American Indian/Alaska Native & 13 & .4 \\
Asian & 307 & 9.4 \\
Black/African American & 249 & 7.6 \\
Hawaiian/Pacific Islander & 13 & .4 \\
Hispanic, all races & 1303 & 39.7 \\
Non-Resident Alien & 63 & 1.9 \\
Two or more races & 5 & .2 \\
Unknown Race/Ethnicity & 183 & 5.6 \\
White & 1145 & 34.9 \\
Total & 3281 & 100.0 \\
Sex/Gender & & \\
\hline Female & 1560 & 47.5 \\
Male & 1655 & 50.4 \\
Unknown & 66 & 2.0 \\
Total & 3281 & 100.00 \\
Age Range & & \\
18 - 21 & 2490 & 75.9 \\
22 - 24 & 272 & 8.3 \\
25 - 34 & 323 & 9.8 \\
Total & 196 & 6.0 \\
& 3281 & 100.0
\end{tabular}

These descriptive statistics are important because they confirmed that the data collected matched the population to be studied as intended. Further, a comparison of this sample population to the general population of Bergen Community College indicates the sample population is representative of the general college population for the Fall 2018 semester for gender, age range, and race/ethnicity (Bergen, 2018a), thus allowing for a more confident generalization to the college's student body. 


\section{Success Indicators}

Two student outcome measures were used as indicators of success in this study: GPA and retention. The mean cumulative GPA earned during the Fall 2018 semester for students who completed the online orientation (1284) is 2.52085 and 2.28712 for students who started but did not finish (790). The mean GPA earned for students who did not access the online orientation program (1207) is 2.30002 .

\section{Table 2}

Descriptive Statistics for Cumulative GPA of Sample Student Population ( $N=3281)$

Mean

Median

Standard Deviation

Range

Minimum

Maximum
2.38334

2.77300

1.375161

4.00

0.00

4.00

\section{Retention}

Another student success indicator is retention. Of the students in the sample, 2462 (75.0\%) were retained from the Fall 2018 semester to register for the Spring 2019 semester, and 819 (25.0\%) students did not return for the Spring 2019 semester.

\section{Analysis of Research Questions}

This section presents the results of this action research study to better understand the impact of participation in an online orientation program on student success by examining GPA and retention as outcomes indicators.

\section{Research Question 1}

Is there a significant difference in the Fall 2018 cumulative GPA earned between students who complete the online orientation program at Bergen Community College and students who do not complete the program?

A one-way ANOVA test was conducted to determine if there was a 
difference in GPA for students who attempted, completed, or did not attempt the online orientation program. The analysis of variance (ANOVA) was selected to find out if the means of GPA for the three research groups were statistically different from each other, and a Bonferroni post-hoc test was run to determine between which groups there was a difference in means.

Results of the test indicate a significant difference among groups of online orientation participation on GPA at the $\mathrm{p}<.05$ level for the three conditions $[\mathrm{F}(2,3278)=10.630, \mathrm{p}=0.000]$. Further post hoc comparisons using the Bonferroni test indicated the mean score for students who completed the program $(\mathrm{M}=2.52085, \mathrm{SD}=1.357354)$ was significantly different from the students who did not attempt the program $(\mathrm{M}=2.30002, \mathrm{SD}=1.390831)$ and students who attempted but did not complete the program ( $\mathrm{M}=2.28712$, $\mathrm{SD}=1.363112)$.

As such, the results suggest a statistically significant difference in cumulative GPA after the first semester for students who completed the online orientation versus students who attempted but did not complete and students who did not attempt the online orientation program. Students who completed the online orientation had a higher mean cumulative GPA after the first semester than students who only attempted or did not attempt the program at all. These data suggest the independent variable (online orientation) may have an impact on student GPA.

\section{Research Question 2}

Is there a significant difference in Fall 2018 to Spring 2019 retention between students who complete the online orientation program at Bergen Community College and students who do not complete the program?

A Chi-Square test of independence was performed to examine the relationship between participation and completion of the online orientation program and retention as a student success outcome indicator. This statistical test was selected to determine if there is a difference in the fall-to-spring retention for students who completed, attempted, or did not attempt the online orientation program.

A significant interaction between these variables was found, X2 (2, N $=3281)=16.27, \mathrm{p}<.01$ where new Fall 2018 students who completed the online orientation were more likely to retain to the Spring 2019 semester 
than students who only attempted or did not access the program at all. These data suggest the independent variable (online orientation) may have an impact on student retention.

\section{Discussion of Results and Recommendations}

The results of this research project are significant and suggest a relationship between participation in the online orientation program and student success. There are statistically significant differences in first semester GPA and first-to-second semester retention for students who complete the program over those students who do not complete the program. These outcomes are consistent with previous research establishing the benefits of participating in new student orientation programs.

Overall, students who completed the online orientation program earned a higher first semester cumulative GPA and retained at a higher level than students who only started or did not attempt the course at all. While no assumptions of causation may be made, the results suggest promising practices related to the usage of online orientation programs in the community college setting.

Most prior literature related to online orientations, specifically at community colleges, focused on the presence, descriptions of content, and implementation of the programs. While a substantial data set was obtained in the research process, this article attempts to offer a select quantitative analysis of the influence the online orientation had on student success outcomes in the first semester as measured by first semester cumulative GPA and first-to-second semester retention. The outcomes measures selected to analyze for this report are consistent with the Early Momentum Metrics defined by the Community College Research Center at Columbia University and align with their measures for early student success (Belfield et al., 2019; Jenkins \& Baily, 2017).

Research indicates participating in new student orientation is a best practice in setting the course for student success, with almost all colleges and universities in the nation offering some type of orientation program 
(Chan, 2017; NODA, 2017). However, most literature related to new student orientation focuses on traditional 4-year college and university populations or online orientation programs for online students and special student populations (Harvey-Smith, n.d.; Nguyen et al., 2010; Robichaud, 2016a). Because little research has been conducted on the effectiveness of online orientation programs and on community college orientation programs in general (Tighe, 2008; Wild \& Ebbers, 2002), this study attempts to offer some introductory information in this area of study.

The increases in participation in the online orientation program compared to participation in the on-campus program at the site of the study hint at the need for new student orientation to be easily accessible. Community college students often face difficulties in attending orientation programs on campus. According to the 2018 CCSSE, 17.1\% of students indicated, "I was unable to participate in orientation due to scheduling or other issues" (Center for Community College Student Engagement, 2018). The availability of the online program may mitigate this factor and enable students with competing priorities and time constraints to benefit from a new student orientation which allows for access whenever and wherever they are.

\section{Limitations}

Consistent with the limitations of participatory action research, this action research study was conducted on a sample population during one semester at a single institution. Because this study is a snapshot in time of one cohort of students at one institution, there are significant limitations, especially in consideration of generalizing the results to a wider higher education population (Stage \& Manning, 2016). However, this research project offers a glimpse into the early results of implementing an online orientation program on participation and student success outcomes measures for a traditional community college student population at a single institution.

Another limitation of this study is the unknown differences in the outcomes considering the differences between full-time and part-time students, as well as the lack of further analysis for variances and trends 
in outcomes for specific demographic groups of students. Additional research should be conducted to replicate this study to add to the results and before making assumptions regarding programming, practice, and policy.

Further, the results of this study assume the quality of the content of the online orientation program and that the program functioned for the duration of the study. There are no known reasons to consider otherwise; however, the researcher believes these are important to note. Given these conditions, there are significant limitations on the ability to generalize the results to a broader college population.

\section{Recommendations for Practice and Research}

The call for student success, accountability, and data-informed decisions continues to drive professional practice for leadership in student affairs and higher education. Based on the outcomes of this study, this section presents recommendations for professional practice and future research.

With a constant focus on improving outcomes, including academic performance, persistence, and completion, the researcher recommends practitioners consider making online orientation programs available for students who are otherwise unable to attend a traditional on-campus program. By making the program a required element of the new student onboarding process, institutions can further ensure students are engaging with critical information to support their academic and personal success in college. While the researcher does not believe an online orientation is a full substitute for a meaningful on-campus orientation program, participation in any orientation program, even in an online format, is preferable to no orientation experience at all.

Most existing literature on online orientations focuses on the development process, content, and delivery of the programs. This action research study attempts to provide a quantitative analysis of selected student success indicators for one cohort of students in a single semester at one institution. The authors recommend conducting additional studies at other institutions focused on the quantitative analysis of student 
success outcomes related to online new student orientation programs. Further research should also include additional indicators aligned with early momentum metrics, such as credits attempted and completed during the first semester (Jenkins \& Baily, 2017).

Other recommendations for related research include tracking the GPA, persistence, and completion of participants over an extended period to assess the longer-term impact of the program. Finally, a qualitative or mixed-methods approach to capture the student experience with online orientation programs could add to a more vibrant picture of how these programs engage students and provide essential tools for students to succeed in the community college environment.

\section{Conclusion}

This study offers a quantitative analysis of two student success indicators, first semester GPA and fall-to-spring semester retention, based on participation in an online orientation program at a mid-sized community college. The results suggest a statistically significant difference in the outcomes measures for students who completed the program over students who began but did not finish the program and students who did not attempt the program at all. While online orientation programs are an evolving tool and may vary greatly in use across institutions, this information may aid community college leaders in defining program initiatives and policy priorities to support student success, help students overcome barriers to persistence, and guide future research. 


\section{References}

21st Century Commission on the Future of Community Colleges (2012). Reclaiming the American dream: Community colleges and the nation's future. Retrieved from http://www.aacc21stcenturycenter. org/wp-content/uploads/2014/03/21stCenturyReport.pdf

Ali, R., \& Leeds, E. M. (2009). The impact of face-to-face orientation on online retention: A pilot study. Online Journal of Distance Learning Administration, 12(4). Retrieved from https://www.westga. edu/ distance/ojdla/winter124/ali124.html

Alijohani, 0. (2016). A comprehensive review of the major studies and theoretical models of student retention in higher education. Higher Education Studies, 6(2), 1-18. http://dx.doi.org/ 10.5539/hes.v6n2p1

American Association of Community Colleges (2018, February). Student persistence and completion. Data Points, 6(4). Retrieved from https://www.aacc.nche.edu/wp-content/uploads/2018/02/ DataPoints_V6_N4.pdf

Bailey, T., Jaggars, S. S., \& Jenkins, D. (2015). Redesigning America's community colleges: A clearer path to student success. Cambridge, MA: Harvard University Press.

Barefoot, B. O. (2005). Current institutional practices in the first college year. In M. Lee Upcraft, John N. Gardner and Betsy O. Barefoot (Eds.), Challenging and supporting the first year student: A handbook for improving the first year of college. San Francisco: Jossey-Bass.

Belfield, C. R., Jenkins, D., \& Fink, J. (2019). Early momentum metrics: Leading indicators for community college improvement. Retrieved from https://ccrc.tc.columbia.edu/media/k2/attachments/earlymomentum-metrics-leading-indicators.pdf

Boyd, B., Largent, L., \& Rondeau, S. (2008). Community College Orientation Basics: How to structure a new student orientation program. Retrieved from NACADA Clearinghouse of Academic Advising Resources website http://www.nacada.ksu.edu/tabid/3318/articleType/ ArticleView/articleId/90/article.aspx 
Bergen Community College. (2018a). Fact Book 2017-2018. Retrieved from Center for Institutional Effectiveness: https://bergen.edu/wpcontent/uploads/Bergen-Community-College-Fact-Book-2017-2018. pdf

Bergen Community College. (2018b). Strategic plan 2018-2023: Re-imagine Bergen. Retrieved from https://bergen.edu/wp-content/uploads/ Strategic-Plan-2018-2023-Reimagine-Bergen.pdf

Center for Community College Student Engagement. (2018). 2018 Community college survey of student engagement. Retrieved from http://www.ccsse.org/survey/reports/2018/standard_reports/ ccsse_2018_coh_freqs_allstu.pdf

Chan, M. (2017). Have you been oriented? An analysis of new student orientation and e-orientation programs at U.S. community colleges. College and University, 92(2), 12-25. Retrieved from https://search. proquest.com/docview/1922864443?accountid=40561

Community College Research Center at Columbia University. (n.d.) Community college FAQ's. Retrieved January 12, 2018, from https:// ccrc.tc.columbia.edu/Community-College-FAQs.html

Cooper, M. (n.d.). Student support services at community colleges: A strategy for increasing student persistence and attainment. Retrieved from Institute for Higher Education Policy: https://www2.ed.gov/PDFDocs/ college-completion/04-student-support-services-at-communitycolleges.pdf

Dynarski, S. (2015, March 11). How to improve graduation rates at community colleges. The New York Times. https://nyti.ms/1KWP8wV Edwards, C., \& Willis, J. W. (2014). Action Research: Models, Methods, and Examples. Information Age Publishing.

Fike, D. S., \& Fike, R. (2008, October). Predictors of first-year student retention in the community college. Community College Review, 36(2), 68-84. http://dx.doi.org/10.1177/0091552108320222

Garza Mitchell, R. L. (2014). Case study: Texas State Technical College Harlingen - online orientation to improve student success. The Community College Enterprise, 20(2), 88-92. http://proxy.library. maryville.edu/login?url=http://search.ebscohost.com/login.aspx?dir ect=true $\& d b=e f t \& A N=100731886 \&$ site=ehost-live 
Gilroy, M. (2010, March 8). Campus tours and college orientations go virtual. The Hispanic Outlook in Higher Education, 20(11), 11-13. https://search.proquest.com/ docview/219285763?accountid=40561

Glass, J. C., Jr., \& Garrett, M. S. (1995). Student participation in a college orientation course, retention, and grade point average. Community College Journal of Research and Practice, 19(2), 117-132. http:// dx.doi.org/10.1080/1066892950190203

Hansen, E., Clark, C. L., McCleish, J. M., \& Hogan, J. R. (2009). Getting to know you: Development of an RN-to-BSN online orientation. Journal of Nursing Education, 48(11), 638-641. http://dx.doi. org/10.3928/01484834-20090828-04

Harvey-Smith, A. B. (n.d.). An examination of the retention literature and application in student success. Retrieved October 15, 2017, from https://www.ccsse.org/center/resources/docs/research/harveysmith.pdf

Hatch, D. K., Mardock-Uman, N., Garcia, C. E., \& Johnson, M. (2018). Best laid plans: How community college student success courses work. Community College Review, 46(2), 115-144. http://dx.doi. org/10.1177/0091552118760191

Huang, H. B. (2010). What is good action research? Why the resurgent interest? Action Research, 8(1), 93-109.

Jacondin, J. (2018). Online orientation data brief: Fall 2017 cohort [Data brief]. Paramus, NJ: Bergen Community College, Center for Institutional Effectiveness.

Jenkins, D., \& Baily, T. (2017). Early momentum metrics: Why they matter for college improvement. https://ccrc.tc.columbia.edu/media/k2/ attachments/early-momentum-metrics-college-improvement.pdf Johnson, K. (2016, Fall). All hands on deck for success: An online orientation project. Summer Academe, 10(1), 2-9.

Jones, K. R. (2013). Developing and implementing a mandatory online student orientation. Journal of Asynchronous Learning Networks, 17(1), 43-45. https://files.eric.ed.gov/fulltext/EJ1011381.pdf 
Jugdev, K., \& Hutchinson, M. (2004, November 15). Online MBA orientation programs: Some best practices. Distance Education Report, 4-6. Juszkiewicz, J. (2017). Trends in community college enrollment and completion data. Retrieved from American Association of Community Colleges: https://www.aacc.nche.edu/wp-content/ uploads/2018/04/CCEnrollment2017.pdf

Karp, M. M. (2011, April). How non-academic supports work: Four mechanisms for improving student outcomes. Community College Research Center Brief, 54, 1-4. https://ccrc.tc.columbia.edu/media/ k2/attachments/how-non-academic-supports-work-brief.pdf Karp, M. M., Hughes, K. L., \& O'Gara, L. (2008, May). An exploration of Tinto's integration framework for community college students. Community College Research Center, 1-20. Retrieved from https:// ccrc.tc.columbia.edu/media/k2/attachments/exploration-tintosintegration-framework.pdf

Koehnke, P. J. (2013). The impact of an online orientation program to improve community college student retention in online courses: An action research study (Doctoral dissertation). https://search-proquest-com.proxy.library.maryville. edu/ education/docview/1426441123/fulltextPDF/ DB3C339A344B4880PQ/1?accountid=40561

National Center for Education Statistics. (n.d.). Data trends. Retrieved August 11, 2019, from https://nces.ed.gov/ipeds/trendgenerator/ Nguyen, A., Hays, B., \& Weinstein, M. (2010, Fall). Showing incoming students the campus ropes: Predicting student persistence using a logistic regression model. Journal of Applied Research in the Community College, 18(1), 16-21. https://search-proquest-com.proxy. library.maryville.edu/docview/868918574? accountid=40561 NODA: Association for Orientation, Transition and Retention in Higher Education. (2017). 2017 Databank Full Report. https://www. nodaweb.org/page/Databank

NODA: Association for Orientation, Transition, and Retention in Higher Education. (n.d.). OTR definitions. Retrieved February 21, 2020, from https://www.nodaweb.org/page/otr_definitions. 
Robichaud, W. (2016a). Orientation programs to increase retention in online community college courses. Distance Learning, 13(2), 57-64.

Robichaud, W. (2016b). Student perceptions of a comprehensive orientation program for online courses (Doctoral dissertation). http://nsuworks. nova.edu/cgi/ viewcontent.cgi?article $=1025 \&$ context=fse_etd

Robinson, D. G., Burns, C. F., \& Gaw, K. F. (1996, Fall). Orientation programs: A foundation for student learning and success. New Directions for Student Services, 75(), 55-68. http://dx.doi.org/10.1002/ ss.37119967507

Scagnoli, N. I. (2001, Fall). Student orientations for online programs. Journal of Research on Technology in Education, 34(1), 19-27. Schneider, M., \& Yin, L. M. (2012, April). Completion matters: The high cost of low community college graduation rates. Education Outlook: American Enterprise Institute for Public Policy Research, 1-10. https:// valenciacollege.edu/ournextbigidea/documents/5_Completion_ Matters.pdf

Stage, F. K., \& Manning, K. (2016). Research in the college context: Approaches and methods (2nd ed.). New York, NY: Routledge. Taylor, J. M., Winn, S. K., \& Dunn, M. (2015, September). Innovative orientation leads to improved success in online courses. Online Learning, 19(4), 114-120. https://files.eric.ed.gov/fulltext/ EJ1079576.pdf

Tighe, W. L. (2008). The impact of participation in a Virginia community college orientation program course on student engagement, satisfaction, academic achievement, and retention (Doctoral dissertation). Available from ProQuest Dissertation and Thesis.

Troyer, D. K. (2015, January). The mission of the community college:

Relevant in 2015? Perspectives: Community College Leadership for the 21st Century, 1-4. https://ferris.edu/HTMLS/administration/academicaffairs/ extendedinternational/ccleadership/alliance/documents/ Perspectives_2015-01January/Perspectives-January2015.pdf Valosik, V. (2014). Innovative Orientations. International Educator, 23(3), 58-61. https://search-proquest-com.proxy.library.maryville.edu/ docview $/ 1525828272$ ?accountid=40561 
Wild, L., \& Ebbers, L. (2002). Rethinking student retention in community colleges. Community College Journal of Research and Practice, 26(6), 503-519. http://dx.doi.org/10.1080/02776770290041864 